\title{
Research on the Financing Operation Mode of Chinese Sewage Treatment Plant
}

\author{
Mariah Zhang ${ }^{1, a}$, Zhu Bin ${ }^{1, b^{*}}$ \\ ${ }^{1}$ Harbin Institute of Technology, Harbin, China \\ a1030775886@qq.com, bzb@hit.edu.cn \\ *Corresponding author
}

\begin{abstract}
At present, according to Chinese construction financing situation of sewage treatment, and through the analysis of the shortcomings existed in the project financing mode,we briefly discuss the BT pattern, listing financing, asset securitization financing, consider that the BT mode, listing and financing mode has clear the role and responsibility between government and enterprises authority, which are more suitable for operation in sewage treatment . In addition, the proposal that combine listing and financing and asset securitization financing may promote the sustainable development of financing mode, then gradually realize the market and operation of the sewage treatment financing to drive the healthy development of the environmental protection industry.
\end{abstract}

Keywords: Project finance financing, BT pattern, Listing financing, ABS.

\section{中国污水处理厂融资运营模式的研究}

\author{
张偲澱 $^{1, \mathrm{a}}$ 朱涁 ${ }^{1, \mathrm{~b}^{*}}$ \\ 1 哈尔滨工业大学管理学院, 哈尔滨, 中国 \\ a1030775886@qq.com, bzb@hit.edu.cn \\ 通讯作者
}

中文摘要：根据我国现阶段的污水处理融资 建设情况, 通过分析项目融资模式普遍存在 的不足，对 BT 模式、上市融资、资产证券 化融资简要论述, 认为 BT 模式、上市融资模 式均具有明晰政府、企业间事权和责权的作 用, 更适合污水处理运营的健康发展。此外, 提出上市融资与资产证券化融资相结合促进 融资模式的可持续发展, 逐渐实现污水处理 的融资以及运营的市场化, 促进环保行业的
健康发展。

关键词: 项目融资; BT 模式; 上市融资; 资 产证券化

\section{1.引言}

随着经济的飞速发展，城市规模的不断 扩大，污水处理问题日益成为制约经济和环 
境可持续发展的重要因素, 污水处理也日益 受到重视。从 2005 年到 2011 年末, 我国城 市污水处理厂总量从 792 家增加到 1841 家，年均增长率为 $22 \%$ 。由于污水处理厂的 建设和运营维护成本都极高, 短期内无法获 得投资回报, 难以有效吸引资金进入污水处 理厂的建设领域，因此投融资问题是发展污 水处理的首要问题。

\section{2.污水处理项目融资模式的不足}

\section{1 投资企业实力参差不齐}

许多项目的主要投资者是中小企业或者 投资者, 这种筹资速度往往较慢且分散, 资 金到位时间长，而且会出现污水处理厂在建 设投入、运营管理以及利益分配等方面揪扯 不清, 影响污水项目的健康发展。另外, 由 于投资者的实力参差不齐，一些企业可能不 具备进行建设的实力, 但是为了拿到项目不 惜进行恶意竞争，这样会导致污水处理厂无 法运营下去，损害社会公众利益。

\section{2 融资前期时间长、过程复杂、成本高}

政府、投资企业和其他相关利益方需要 签署的一系列的协议、合同以保证利益方的 利益以及污水处理厂项目的成功实施。由于 涉及的相关利益方较多且特许经营期较长, 往往很难让所有相关者在这样长的时间内各 自的利益得以保障。所以, 污水处理厂项目 前期的工作烦琐而复杂, 较长的时间和磋商 使得污水处理项目融资成本也相应增加。

\section{3 污水处理厂的移交风险}

政府在接收污水处理厂时很可能会出现 投资者在运营期的最后几年，从自身利益角 度，对设备的维护等认为没有投入的必要， 仅为了获得污水处理费用, 移交时污水厂已 经部分或全部丧失处理能力。而随着科学技 术的发展, 污水处理工艺在 20 年间一定会产 生巨大的突破和发展, 新工艺将拥有更佳处 理效果和更低处理成本, 在政府接收污水处 理厂后, 即便可运行, 但工艺的运营成本会 相对较高。投资者在运营相当长的一段时间 后，投资成本基本收回并取得了一定的回报， 在面临设备陈旧需要投入大量资金维护或更
新以及其他突发状况时, 再运营不符合自身 的利益, 就很有可能提前移交。

\section{3.污水处理投融资模式的选择}

在我国现阶段, 出现大量以项目融资为 主要模式的污水处理厂融资, 在融资中若处 理不好相关利益方间的利益关系, 每一次的 融资前期工作都需要进行大量筛选, 增加了 融资成本高。故而, 针对我国国情以及污水 处理厂融资建设的需求, 本文认为我国污水 处理可以采用 BT 模式和上市融资模式为主, 满足了污水处理的融资建设, 然后在相关制 度完善的情况下, 兼纳资产证券化融资模式, 进行污水处理大规模融资。

\section{1 污水处理融资的 BT 模式}

BT（Build-Transfer）模式是 “建设一 移交” 的简称, 该模式先由建设方负责项目 的投融资和建设，由银行或其他金融机构根 据项目的未来现金流对项目进行评估，为建 设方提供不同额度的贷款，污水处理项目在 交由建设方完成建设后，从建设投资方移交 给政府部门, 政府部门按照合同规定对建设 方的资金进行偿还，建设过程中政府部门仅 行使对污水处理项目的监管权。

\section{1 .1 融资运营成本减少}

政府无需投入资金即可建成污水处理 厂，还款期相对较短，对投资者获得的投资 回报可计算和控制，减轻了政府的财政负担。 污水处理厂由政府运营，政府只需付出最基 本的处理成本，而且收取的排污费已能保证 污水处理的成本, 无需财政补贴, 污水处理 厂完全能够自给自足。另外, 污水处理的中 水回用又可以给政府带来巨大的收益。

\section{1.2 融资前期工作减轻}

项目融资前期工作，操作更加规范，风 险降低, 使得融资成本减少。此外, 投资者 并不参与污水处理厂的运营, 减少了合同谈 判的烦琐，时间和投入也大为减少。

\section{1 .3 统一维护管理规范}

污水处理厂建成后交由政府运营，纳入 市政整体水循环体系进行统一管理维护, 收 
费合理, 管理规范, 将更好的保证污水厂正 常的运行, 同时也避免了企业、政府和其他 相关利益方间可能出现的纠纷, 保障了社会 大众的利益。

\section{2 污水处理厂的上市融资模式}

就当前的政策环境和经济制度情况而 言, 可以由政府公开招标篮选经济状况良好 和未来发展前景看好的环保或水务股份有限 公司，该股份公司通过上市进行股权融资， 融资成功后由环保公司经过合理设计、外包 建设污水处理厂, 并对污水处理厂进行经营 管理, 而政府授予其在一定范围和期限内经 营该污水处理业务的特许权, 并对污水处理 质量进行监管，如图 1。

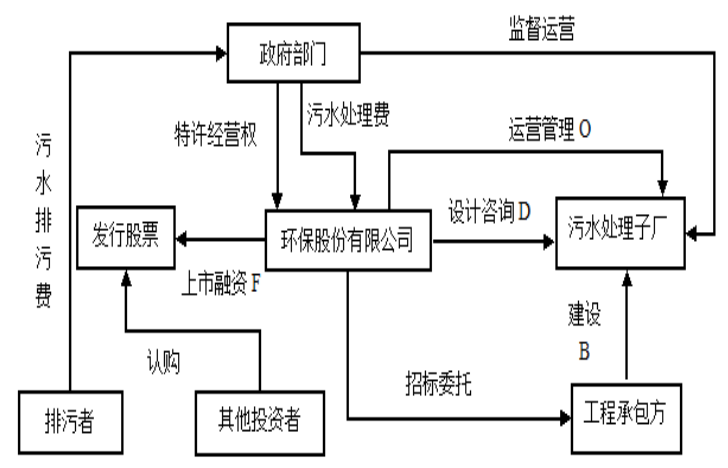

图1 污水处理厂PFDBO融资运营模式

\subsection{1 股份有限公司股权融资模式的优势}

（1）股份有限公司在组织结构上都相对 成熟，具有良好的社会声誉和较强的融资能 力, 鼓励其上市融资，不仅可以保证篮选的 是真正具有资金和技术实力的企业，避免了 恶意竞争，同时可以实现对污水处理厂建设 的融资, 扩大企业自身发展资本的获得, 拓 展企业生存发展空间。故而选择股份公司上 市融资是基于成熟的组织结构，以及良好的 社会声誉, 较强的强融资能力, 较快的融资 速度，保证融资的成功和资金的迅速到位。

（2）股份有限公司基本融资方式有债务 性融资和股票融资。污水处理厂相对是个资 金需求较大的项目，且污水处理投资回报周 期较长, 贷款需要抵押和担保, 还易受到宏 观经济环境的影响, 融资渠道相比较单一, 而债权融资难以满足污水处理厂的要求，无 法充分配置资源，股权融资在我国发展相对 健全和稳定。所以，选择股权融资能够较好
的满足目前我国污水处理厂投资回报周期 长、资金需求大的融资需求。

(3) 污水处理厂的筹建需要大量资金等 资源的投入，鼓励股份有限公司上市融资有 利于集中社会闲散资金进入环保产业，促进 环保行业快速成长，同时，培养环保行业污 水处理厂融资的中坚力量, 在需要进行污水 处理厂建设融资时能够有真正具备实力的企 业参与融资的竞争, 实现污水处理厂建设的 健康运营, 同时也为上市后的股份公司未来 实现部分业务资产证券化模式提供基础, 使 其具有大规模的融资能力。

(4) 公私合营需要政府与企业的相互合 作, 但这里的公私合营强调当把经营权和盈 利权由企业主导, 避免企业为获取短期政府 补贴或者盈利, 套用环保概念在股票市场上 圈钱, 相应地政府仅承担监督管制作用, 由 市场主导融资, 实现传统的融资由政府主导 投融资的转型。对政府来说, 污水处理需要 达标并改善环境, 获得了社会效益, 但是对 企业来说, 需要获得预期回报, 如果政府或 者政策干扰过多，会严重打击企业的积极性， 故需以此明晰政府、企业之间的环境责权和 事权。

\subsection{2 政府在上市融资中的作用}

由于污水处理的投资相对稳定，即使考 虑相关因素, 污水处理厂在建成后，一般企 业在获取的污水处理费减去实际的处理成本 后, 其利润能在七至十年内将投资全部收回。 政府根据获利污水处理厂污水处理量, 在扣 除一定税费后向企业支付处理费用。由政府 征收处理费, 再以经营性处理费支付给企业, 不仅可以保证处理费用征收的稳定性, 还可 以作为对企业监督管理的一种手段，防止具 有垄断性的企业为了获得高利润设置不合理 的处理费造成的人为增加环保成本，损害公 众利益，同时，政府也可获得合理的财政收 入。

随着自有技术和设备、耗材国产化的加 强，污水处理成本将进一步减少，投资者的 利润也会相应增加, 政府可以在保障企业利 润的情况下，对排污费进行适当调整。从而 既可以保障污水处理的发展, 又可以保障技 
术的发展和处理成本的降低给社会带来实 惠。

污水处理厂的利益相关方涉及政府行政 部门、投资方、管理层以及社会大众。现阶 段，非上市公司形式的污水处理厂均拒绝对 社会公众披露相关财务信息，致使污水处理 厂的真实运行状况和基本财务信息难以被利 益相关者获得，导致相关决策的低效甚至无 效。所以, 政府需要行使监督权, 利用互联 网等手段对重要信息进行公开披露, 增强以 污水处理成本为核心的污水处理信息的透明 度，降低信息不对称所导致的代理冲突问题。

\section{3 污水处理的资产证券化融资}

\section{3.1 股份有限公司实现资产证券化的基础}

在我国，合伙股份的出让须全体合伙人 同意，因此不宜设质。公司股份设质，根据 有限责任公司和股份有限公司的性质，前者 根据我国《担保法》的规定，适用《公司法》 的有关规定，有严格的法律限制。只有股份 有限公司的股份，以公司发行的股票为表现 形式，在交易场所可依法自由转让，因而最 适宜设质。

\section{3.2 资产证券化概论}

ABS (Asset-Backed-Securitization) 即 资产支持的证券化融资，是以目标项目未来 预期收益为保证，通过在国际资本市场上发 行高档债券来筹集资金的一种项目融资方 式, 其目的在于把原先信用等级较低的项目, 利用提高信用等级的方式，使其有资格进入 国际高档债券市场, 并利用该市场信用等级 高, 债券安全和流动性高, 证券利率低的特 点，大幅度降低发行债券、筹集资金的成本。 如图 2 所示。

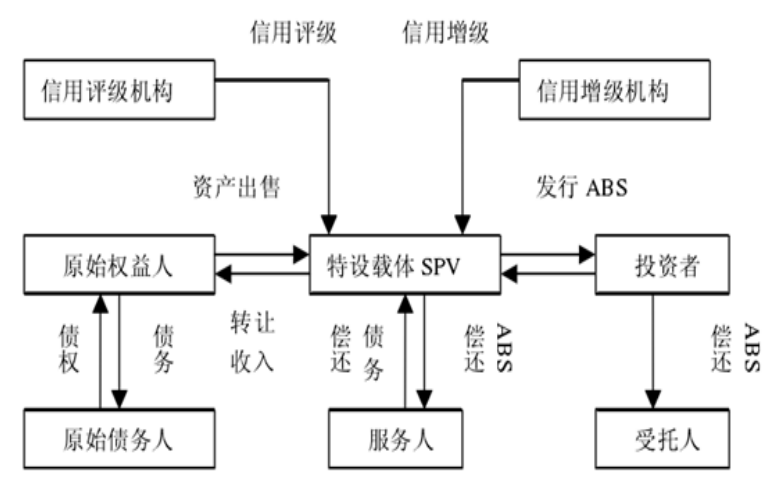

图2 污水处理厂 $\mathrm{ABS}$ 融资模式

\section{3.3 污水处理进行资产证券化的可行性}

首先, 资产证券化通过在国际高档债券 市场发行证券，高信用等级使其具有较好的 二级市场，投资者数量较多，可降低投资者 的投资风险。其次, 资产证券化通过信用增 级, 使得原先一些流动性较差的资产组合后 可以进入国际高档证券市场上发行那些易于 销售、转让以及贴现能力强的高档债, 同时 其按市场规则运行，无需政府的许可、授权 及外汇担保, 减少很多中间环节, 从而也可 以降低融资成本。再者, 资产证券化有效实 现了项目经营权与所有权的分离, 具有更广 泛的适用范围。SPV 拥有项目的所有权, 经 营决策权仍归原始权益人所有。

在技术相对成熟、能源消耗逐渐降低的 情况下，污水处理厂将具有良好的社会经济 效益，可以产生稳定且可预测的现金流，符 合资产证券化的要求。污水处理厂因由政府 保障收入, 其经营风险较低, 且不易受到经 济周期的影响，同时，未来参与主体也会日 益成熟。

\section{4 上市融资与资产证券化融资模式的结 合}

通过资产证券化可以使优质资产注入上 市公司，不断增强上市公司的获利能力，使 整体质量得到提高, 减少委托代理的层级, 解决公司利益相关方的激励与制衡问题, 有 效提高上市公司的决策效率与运营水平，有 助于实现资产的有效整合，提高整体资产的 运营效率及效果。通过上市融资增强企业自 身实力, 形成环保行业基础设施融资建设的 中坚力量, 然后进行部分资产证券化满足污 水处理的融资需求, 实现污水处理融资模式 的可持续发展，促进环保行业的发展。如图 3 所示。 


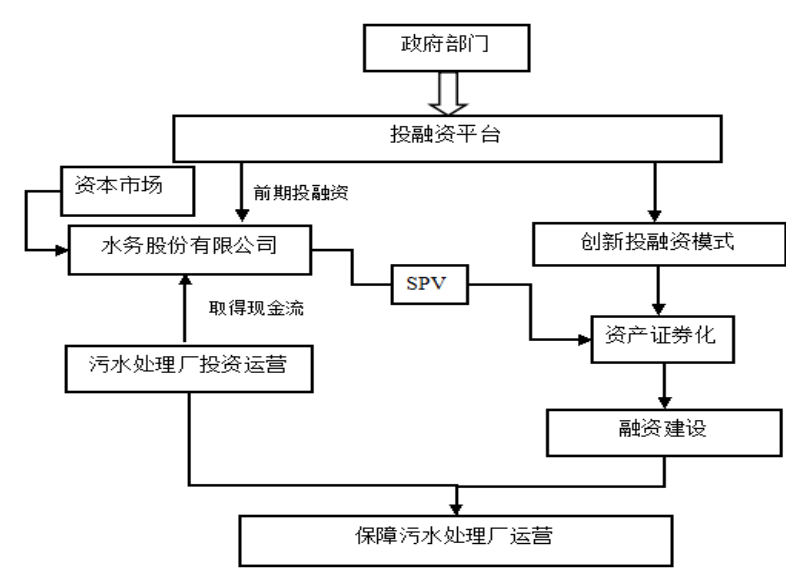

图3 污水处理可持续的融资模式

由于我国现阶段资产证券化仍存在相法 律法规、监管执行、信用评级以及税收制度 等不完善的问题, 所以现阶段选择资产证券 化方式进行融资存在着较大风险。但是随着 以上问题的逐渐解决, 资本市场以及政策法 律相对完善, 在上市公司经营状况良好的情 况下, 可以在不改变其股权结构等的基础上, 由政府部门牵线, 对其资产进行部分证券化, 实现大规模的污水处理厂设施建造的融资。

\section{4. 结束语}

污水处理存在融资难、政府与企业纠纷 不断, 导致污水处理厂不能长久健康发展的 问题, BT 模式划分了政府和投资者在污水处 理项目中的时间段, 避免了这些问题; 而上 市融资明确了政府和投资者在整个过程中的 角色, 明晰了责权和事权, 适当给予协议规 范, 也能将影响降到最小; 资产证券化融资 需要成熟的金融市场, 既适用上市公司部分 资产证券化, 有利于中小企业融资, 实现大 规模融资。上市融资与资产证券化融资的结 合，有利于形成一种可持续发展的融资模式， 逐渐实现污水处理的融资以及运营的市场 化, 促进污水处理融资运营的健康发展。

\section{References}

[1] Ofwat.Consultation on Market Competition in the Water and Sewerage Industries in England and Wales, 2007.

[2] Sun Maoying. Research on investment and financing problem of water industry [D].
Dongbei University of Finance and Economics, 2013

[3] Gen Jianxin, Li Zhijian, Still Huijun. Sewage treatment plant in the future construction mode and measures study -Based on the fiscal and financial point of view of the analysis [J]. Environment and sustainable development, 2014,39:(1).DOI:10.3969/j.issn.1673-288X .2014.01.012.

[4] Zhang Yi. Our city sewage treatment plant of $[\mathrm{J}]$. investment and financing mode of economic perspective Kan, 2014, (5).

[5] Xiao Shirui. Analysis of the financing mode of urban infrastructure projects in China $[\mathrm{J}]$. infrastructure management optimization, 2015, (1). 